\title{
The hybrid tool for operations of cleaning of turbine units cavities
}

\author{
Vitalii Tkachuk $^{1} \bullet$ Viktor Shchetynin $^{1} \bullet$ Sergii Shlyk $^{1} \bullet$ Olga Chencheva $^{1} \bullet$ Oleksandr Salenko ${ }^{2}$ \\ ${ }^{1}$ Kremenchuk Mykhailo Ostrogradsky National University, Kremenchuk, Ukraine \\ ${ }^{2}$ Igor Sikorsky Kyiv Polytechnic Institute, Kyiv, Ukraine
}

Received: 23 April 2020 / Accepted: 24 May 2020

\begin{abstract}
The paper deals with the hybrid action tool for cleaning of cavities and elements of turbine units whose operation is based on a combination of action of a water-ice flow with mechanical shock influence of the small concentrated masses mounted on elastic suspensions. Receiving energy from the flow, the masses, performing self-oscillating motion, come into contact with the treated surface having a layer of strong contamination, and create a multipoint shock-cyclic loading of the surface, which results in active development of initial defects of the contamination film, due to which the following action of the water-ice stream produces better and more productive cleaning. It is shown that the generated local stresses, determined on the basis of Hertz contact problems, reach 15-20 MPa, do not have a significant effect on the surface of the base, which is a thin curves shell, do not change the state of its surface in the plane of adhesion, but result in defects in surface film in the form of cracks and delaminations. In this case the film is eliminated by water-ice flow more dynamically. The use of water-ice jet, formed by the original tubeless device, enables the formation of a wide flow (with the top angle of $\pi / 12 \ldots \pi / 6$ ) and the work of its ice particles is spent on grinding the surface film. The jet stream cleans the surface and removes the products of destruction beyond the impact.

The use of a hybrid tool has increased the productivity of treatment with the wetting angles of the jet flow, different from $\pi / 2$, by more than $30 \%$, while the consumption of cryogenic liquid (liquid nitrogen) is reduced by $20-25 \%$.

The process modeling is performed, the conditions of the destruction of the adhesive bond of the contaminant film with the surface are estimated, the conditions of its rational execution are determined.

Keywords: hybrid tool, water-ice flow, surface cleaning, modeling, surface mud films.
\end{abstract}

\section{Introduction}

Turbine units are most used among the means for obtaining mechanical work of significant power during fuel combustion. They are used in aviation technology, in generating electricity, as working machines in shipbuilding, on highways for pumping gaseous substances, etc. Such units are of a high specific power, have no articulated links (as opposed to internal combustion engines), are steady in operation. However, turbines require clearer and deeper maintenance, a number of additional operations to check the rotor for defects and initial damage.

Operations of cleaning of elements and systems are part of a complex of technological service and are directed to removal of both plastic viscous pollution (for example, in greasing systems, heat exchangers) and the strong surface films possessing high adhesive durability to a surface.

Usually when carrying out such cleaning operations, solvents, special washing liquids are used. However, such methods are not only extremely dangerous, but also environmentally harmful, require the solution to the problems of aspiration and ventilation, as well as the subsequent separation of cleaning products.

An alternative to this method of purification is jet, using the formed jets of high pressure fluid (up to $60 \mathrm{MPa}$ ). Such technologies are used by a number of airlines (including Luft Hansa). At the same time, the selective ability of the jet to flow around obstacles, elastic properties of the substrate, the difference in the strength of the contaminant layer on the surface causes the need to perform processing with a large number of passes, to carry out constant visual and

Oleksandr Salenko

salenko2006@ukr.net 
instrumental cleaning. Besides, jet cleaning methods require additional operations aimed at ensuring the reliability of the removal of the surface layer, which necessitates the search for effective means to improve the efficiency of such processes in practice.

It is known from papers $[1,2]$ that it is possible to increase the ability of the jet to perform local work of destruction both by the introduction of special chemical additives (in order to more actively manifest the Rebinder effect or to activate chemical processes and phenomena), and by changing the phase of the jet, for example when saturating the latter with abrasive particles. In these two cases the mechanism of interaction of the flow with the surface (and, accordingly, with the dirty surface film) changes, which results in increased productivity of the cleaning process.

Since the use of water-abrasive flow is impossible (in this case, the parameters of the surface layer will change), it is advisable to find new ways to intensify the process of extraction of surface layers, in particular through the use of water-ice jet. Such technologies are used in the processing industry (for example, for cutting meat briquettes) practically do not harm the surface layer of metals and alloys, but have more pronounced cutting properties due to the flow of hardened ice particles.

Due to the fact that the processes of water-ice treatment are promising and environmentally friendly, such operations can be successfully used in the practice of cleaning the internal cavities of turbines.

Papers $[3,4]$ note that increasing the efficiency of jet methods is possible in several ways. For cutting operations, the goal is achieved by using more efficient nozzles, and work is carried out with high pressures of process fluid (water). In this case the thickness of the displaced layer at the boundaries of the nozzle decreases, and it is possible to achieve greater compactness of the jet; therefore, the hydrodynamic action of the flow is concentrated on a smaller plane and is more efficiently spent on the local destruction of near-surface microvolumes of material.

The authors [5] propose to increase the efficiency of processing by changing the stress state in the cutting zone. Thus, the application of intensifying forces capable of causing tensile stresses in the surface layers of a thin workpiece (in the form of a shell) increases the activity of crack formation, the cracks are more intensely opened and the productivity of the process grows. However, there is also the possibility of losing control of the process, which may result in avalanche-like destruction of the material in the direction of its least resistance to the applied intensifying forces.

Prospects for combining different in nature effects on the treatment area in order to change the quality, productivity or reliability of the process are discussed in detail in [6]. The authors propose to analyze the level of hybridization and search for such material carriers that would ensure the maximum level of this parameter, provided that the additional material costs are minimal. The main condition for the effective implementation of such an approach is the condition of process control.

Taking into account the above said, the purpose of the paper consists in substantiation of the expediency of hybridization of a method of water-ice purification with the means of influence initiating emergence and active development of initial defects in a pollution melting and on a surface "basis-film".

\section{Research methods}

The use of ice particles instead of abrasive particles is promising and effective in terms of environmental friendliness of the method, the relative ease of disposal of treatment products (the need for separation of sludge eliminates), the wide technological capabilities of the method. The processing productivity in the comparison of water abrasive and water jet methods is intermediate [7].

The following features of the process are typical of cleaning operations:

- surface films have excellent properties, can be elastic, hard, brittle, have different adhesion to the base surface;

- usually the physical and mechanical properties of the film of the contaminant and the base have significant differences;

- the interaction of the jet flow and the film on the base occurs in non-stationary conditions;

- depending on the conditions of jet flow, the mechanism of interaction is fundamentally different;

- when cleaning the surface from film contamination, surface damage is undesirable (and in some cases generally unacceptable).

Therefore, despite the significant number of existing cleaning methods (Table 1), mainly method 1 and partly 3 are used for operations with the elements of turbine units. The analysis of turbine blade cleaning methods, described in detail in [8], allows concluding that currently there is no single approach to the problem of removing products of hightemperature oxidation and sulfide corrosion of heat-resistant alloys based on $\mathrm{Ni}$.

At the same time, we can assume that the use of ice flow enables the process of removing surface films by the mechanism of jet-abrasive wear, in which ice particles damage the film surface and form initial cavities, and jet flow, carrying out hydrodynamic loading of the surface, further destroys the film and removal of destruction products outside the impact zone. 
Table 1. Comparative characteristics of surface cleaning methods

\begin{tabular}{|c|c|c|c|c|}
\hline \multirow{2}{*}{\multicolumn{2}{|c|}{$\begin{array}{c}\text { Method of cleaning and } \\
\text { equipment }\end{array}$}} & \multicolumn{3}{|c|}{ Characteristic of the method } \\
\hline & & Application & Advantages & Drawbacks \\
\hline 1 & $\begin{array}{l}\text { Chemical (etching): baths } \\
\text { for etching }\end{array}$ & $\begin{array}{l}\text { for products of different } \\
\text { sizes and materials }\end{array}$ & $\begin{array}{l}\text { suitable for any surface } \\
\text { configuration. }\end{array}$ & $\begin{array}{c}\text { requires utilization of the spent solution, } \\
\text { washing and drying of preparations; the } \\
\text { base metal is removed together with the } \\
\text { scale }\end{array}$ \\
\hline 2 & $\begin{array}{l}\text { Mechanical: roughing and } \\
\text { grinding machines, hand } \\
\text { tools, blade tools }\end{array}$ & $\begin{array}{l}\text { for simple-shape } \\
\text { workpieces without } \\
\text { recesses }\end{array}$ & $\begin{array}{l}\text { does not require } \\
\text { significant material } \\
\text { costs for production } \\
\text { preparation }\end{array}$ & $\begin{array}{c}\text { low productivity; suitable only for simple } \\
\text { workpieces; surface roughness is not } \\
\text { controlled }\end{array}$ \\
\hline 3 & $\begin{array}{c}\text { Hydrojet and hydro- } \\
\text { abrasive: hydro- and } \\
\text { hydroabrasive equipment }\end{array}$ & $\begin{array}{l}\text { to remove surface } \\
\text { defects, scale and } \\
\text { contaminants }\end{array}$ & $\begin{array}{l}\text { suitable for cleaning } \\
\text { surfaces of complex } \\
\text { shape; provides high } \\
\text { quality and low } \\
\text { roughness }\end{array}$ & $\begin{array}{l}\text { the cleaned surface of blanks rusts } \\
\text { quickly, and needs drying; high cost and } \\
\text { energy consumption of equipment }\end{array}$ \\
\hline 4 & $\begin{array}{l}\text { Pneumatic-abrasive: } \\
\text { sandblasting units }\end{array}$ & $\begin{array}{l}\text { to eliminate small } \\
\text { defects and fine } \\
\text { grinding }\end{array}$ & $\begin{array}{c}\text { suitable for cleaning } \\
\text { surfaces of complex } \\
\text { shape }\end{array}$ & $\begin{array}{l}\text { the method is very energy intensive and } \\
\text { dangerous; requires a large amount of } \\
\text { sand; dust formation }\end{array}$ \\
\hline 5 & $\begin{array}{l}\text { Vibrating: vibrating } \\
\text { equipment }\end{array}$ & $\begin{array}{l}\text { for forgings with } \\
\text { shallow relief and } \\
\text { complex geometry }\end{array}$ & $\begin{array}{c}\text { high productivity, } \\
\text { possibility of processing } \\
\text { of details of the simple } \\
\text { form }\end{array}$ & use of fractions \\
\hline 6 & $\begin{array}{l}\text { Tumbling: tumbling } \\
\text { drums }\end{array}$ & $\begin{array}{l}\text { for any workpieces of } \\
\text { small relief and without } \\
\text { ribs }\end{array}$ & $\begin{array}{l}\text { low cost; used to clean } \\
\text { small workpieces of } \\
\text { simple shape }\end{array}$ & $\begin{array}{c}\text { poor cleaning of parts of complex shape, } \\
\text { the appearance of dents on the surface; } \\
\text { curvature of long forgings; significant } \\
\text { noise level }\end{array}$ \\
\hline 7 & $\begin{array}{c}\text { Fraction: fraction blasting } \\
\text { and fraction jetting } \\
\text { machines }\end{array}$ & $\begin{array}{l}\text { for medium and large } \\
\text { workpieces without } \\
\text { holes and depressions }\end{array}$ & $\begin{array}{l}\text { quick cleaning of } \\
\text { simple surfaces }\end{array}$ & $\begin{array}{c}\text { changing the properties of the surface } \\
\text { layer of the workpiece; high fraction cost; } \\
\text { significant noise level, poor surface } \\
\text { roughness }\end{array}$ \\
\hline 8 & $\begin{array}{l}\text { Physical (Thermal): } \\
\text { plasma installations, } \\
\text { cleaning with cryogenic } \\
\text { blasting }\end{array}$ & $\begin{array}{l}\text { for cleaning of medium } \\
\text { and large workpieces }\end{array}$ & ease of use & unproductive, requires further machining \\
\hline 9 & $\begin{array}{l}\text { Physical (ultrasonic): } \\
\text { ultrasonic equipment }\end{array}$ & $\begin{array}{l}\text { cleaning of parts from } \\
\text { pollution }\end{array}$ & $\begin{array}{l}\text { it is possible to clean } \\
\text { parts of complex shape } \\
\text { or with holes }\end{array}$ & $\begin{array}{l}\text { Limited to the cavitation stability of the } \\
\text { workpiece surface; additional costs of } \\
\text { detergents; fatigue cracks may form }\end{array}$ \\
\hline
\end{tabular}

Assume that the workpiece is a flat shell with a thickness $h_{0}$ and a curvature $r$, on the surface of which there is a layer of contamination with thickness $h_{z}$. Usually in turbines this layer has quasi-brittle properties, the characteristics of which are given in the Table.

The instrument that forms the water-ice flow, usually uses a cryogenic liquid to cool the water jet, and the development of the shell of the latter and the position of the core determine both the heat transfer efficiency between liquid droplets and the efficiency of kinematic pulse transmission. Despite the fact that the temperature at the time of mixing can reach 110-130 K, and the heat transfer time, compared with the time of the particle travel to the surface, is a few $\mathrm{ms}$, ice particles rather quickly pass unstable states of ice II (of a trigonal shape) via ice $L_{c}$ (metastable cubic particles) to the state of ice $L_{h}$, of a usual hexagonal shape. Having a more rounded shape, the particles lose their cutting ability, and perform mainly the compression of the surface and the disclosure of the initial defects. The following active heating of the particles further reduces the flow activity, so to ensure the normal course of the cleaning process there is a need to bring additional energy to the treatment area, able to actively develop film defects.

Let this influence be the momentum of force transmitted by solid concentrated masses $m_{i}$ during their oscillating motion with contact with the treated surface in the zone of influence. If it is necessary to treat the surface with curvature $r$, size $B x L$ and thickness $h_{0}$ to which a layer of contaminant $h_{z}$ is applied, the particles will form on the surface of the zone of elastic shocks, in accordance with Fig.1, denoted $K_{i}$. 


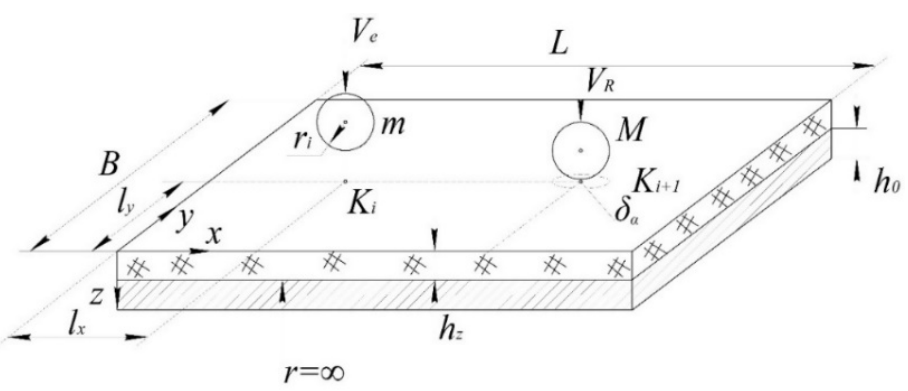

Fig. 1. Interaction of a two-layer shell with solids of small size

Assuming that the points of contact are determined by coordinates $l_{x}, l_{y}$, and at the moment of impact the elastic deformations will cause the appearance of tangential stresses on the adhesion surfaces, it is easy to determine the conditions under which the deformations of the base will be in the elastic zone, while $\left[\sigma_{\mathrm{a}}\right]$, $\left[\sigma_{\mathrm{p}}\right]$ will undergo significant changes.

The stresses at the point of contact can be determined by the appropriate Hertz formulas, which for the case of contact of a solid body represented as a sphere of radius $r_{1}$ contact surface in the form of a thin shell with a radius $r_{2}$ will make $\sigma=\frac{m F^{1 / 3} E^{2 / 3}}{r^{2 / 3}}$, where $m=1+\frac{r_{1}}{r_{2}}, E-$ reduced elasticity modulus, $E=\frac{2 E_{1} E_{2}}{E_{1}+E_{2}}, r-$ reduced radius of the contact, $\frac{1}{r}=\frac{1}{r_{1}}+\frac{1}{r_{2}}$

Since the surface of the film is not homogeneous, equal in thickness and structure, has certain initial defects, the theoretical description of the behavior of the film under the action of mechanical action and the influence of water-cross flow is complex and quite conditional. Therefore, to determine the conditions and features of the interaction of solids with the elastic medium of the shell, the process modeling in the software product ANSYS is performed.

The conditions of modeling are given in Table 2, and an example of the obtained results - in Fig. 2. The modeling shows that on thin shells, stresses that can cause a significant reduction in adhesion to the substrate propagate from the point of action of the concentrated mass at a distance of up to $10 d_{m}$ at angles $25^{\circ}-35^{\circ}$ relative to the line of impact of the body, which generally corresponds to the linear mechanics of elastic bodies.

Table 2. Conditions for modeling the process of shock-dynamic impact of small bodies with elastic bonds

\begin{tabular}{|c|c|c|c|c|c|}
\hline No. & Parameter & Value & No. & Parameter & Value \\
\hline 1 & Base material & $\begin{array}{c}\text { Heat-resistant } \\
\text { alloy based on } \mathrm{Ni}\end{array}$ & 5 & Contamination layer & $\begin{array}{l}\text { Sulfide corrosion } \\
\text { particles and fuel } \\
\text { scale }\end{array}$ \\
\hline 2 & Base thickness, mm & 0.25 & 6 & Film thickness, $\mathrm{mm}$ & 0.05 \\
\hline 3 & $\begin{array}{l}\text { The modulus of elasticity of } \\
\text { the base, GPa }\end{array}$ & 130 & 7 & $\begin{array}{l}\text { The modulus of elasticity of the } \\
\text { film, GPa }\end{array}$ & 70 \\
\hline 4 & Yield strength, $\mathrm{MPa}$ & 840 & 8 & Bending strength, $\mathrm{MPa}$ & 0.85 \\
\hline \multicolumn{6}{|c|}{ Solids and shape of the modeling zone } \\
\hline 9 & Surface size & $100 \times 50$ & 12 & Solid body material & $\begin{array}{c}\text { Hardened steel } \\
40 \mathrm{X}\end{array}$ \\
\hline 10 & $\begin{array}{l}\text { Surface radius of curvature, } \\
\mathrm{mm}\end{array}$ & $\propto$ & 13 & Modulus of elasticity, GPa & 215 \\
\hline 11 & Solid body radius, $\mathrm{mm}$ & 2.0 & 14 & Yield strength, $\mathrm{MPa}$ & 700 \\
\hline
\end{tabular}

In addition to the shock-dynamic, the film absorbs the load from the action of ice particles and the flow of liquid. In Fig. 3 the inflow of the flow on the surface occurs at an angle $\alpha$, by a jet of diameter $d_{c}$. The average jet flow velocity is determined by the geometric parameters of the jet (opening angle $\beta$ ), the distance from the nozzle cut to the treated surface $H$, as well as the flow losses in the air:

$$
\bar{v}=\frac{1}{2} v_{c}\left(1+k_{p}\right)
$$



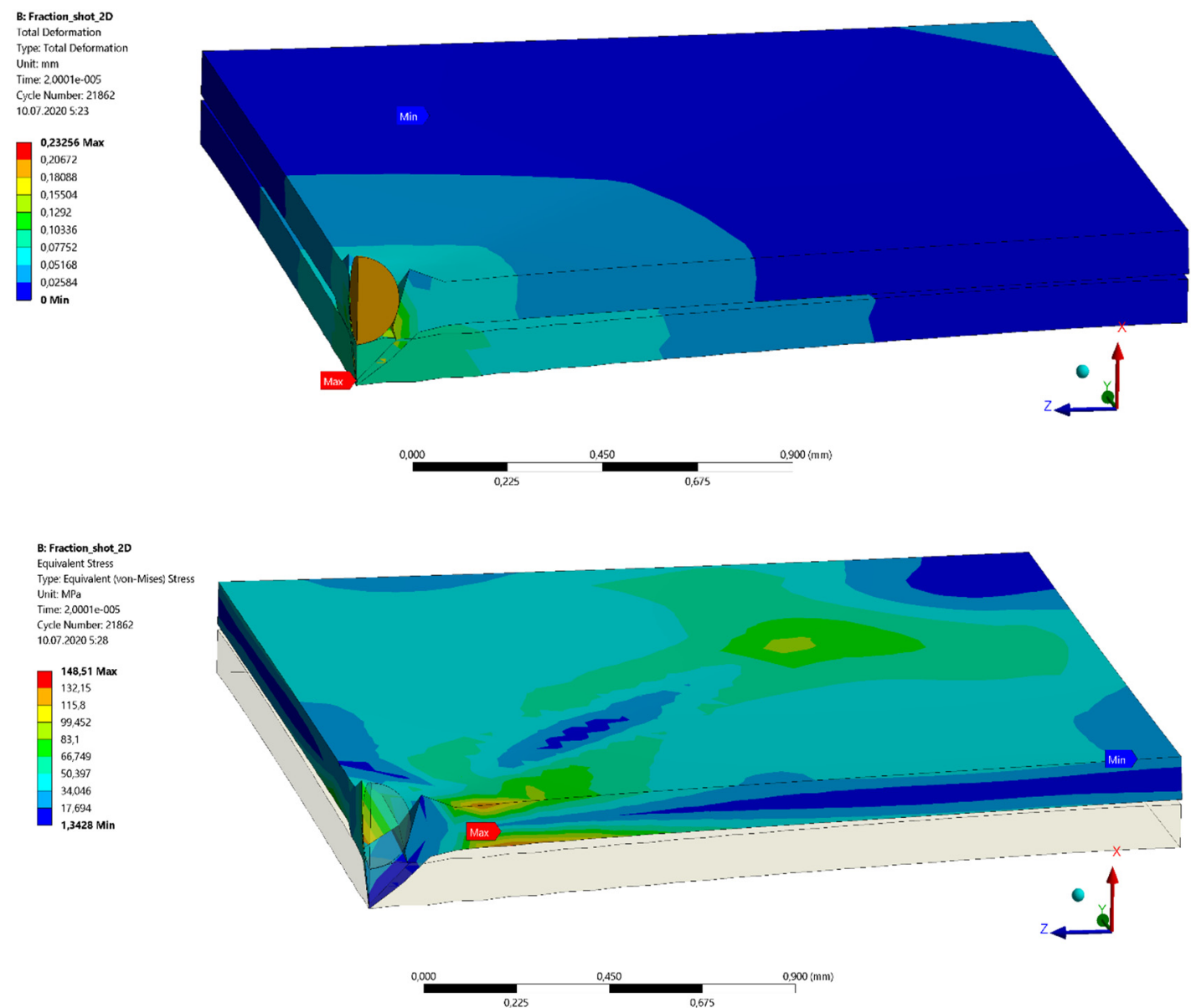

Fig. 2. The results of modeling the action of a solid of mass $m$ and radius $r_{i}$ on a thin plate with a layer of contamination

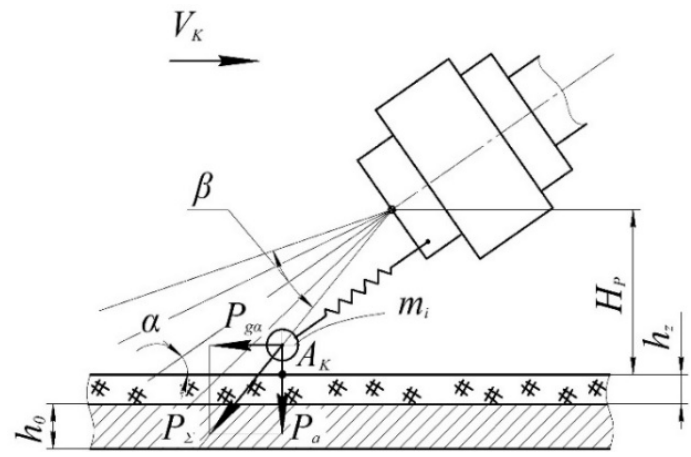

Fig. 3. The scheme of interaction of the hybrid tool with the treated elastic thin-walled workpiece

where $k_{p}=\frac{d_{c}^{2}}{4\left[\frac{d_{c}}{2}+H \sin \left(\frac{\beta}{2}\right)\right]^{2} \cos ^{2} \alpha}$.

Given that the mass of the liquid column, which is a truncated cone and is located between the slice of the nozzle and the treated surface, will be defined as

$$
m=\rho V, v=\left(r^{2}+R^{2}+r R\right) \frac{\pi H}{3},
$$

$R$ - the radius of the smaller half-axis of the ellipse in the projection of the flow cone on the flat surface of the inflow, the average value of the kinetic energy possessed by the jet performing the work of destruction will be: 


$$
K=\frac{\pi \rho H}{24}\left(\frac{d_{c}^{2}}{4}+R^{2}+R \frac{d_{c}}{2}\right) v_{c}^{2}\left(1+k_{p}\right)^{2} .
$$

The kinetic energy of the flow will be partially spent on maintaining the self-oscillating process of a system of small bodies with elastic bonds, which carry out the shock load of the surface and the motion of which is described by known differential equations

$$
m_{i} \frac{d^{2} x_{k}}{d t^{2}}-v_{k} \frac{d x_{k}}{d t}-c_{1} x_{k}=R_{g d x}, \quad m_{k} \frac{d^{2} y_{k}}{d t^{2}}-v_{k} \frac{d y_{k}}{d t}-c_{3} y_{k}=R_{g d y},
$$

$R_{g d}$ - hydrodynamic influence by the corresponding coordinates, will be spent on dispersal of the generated ice particles, and finally - on destruction of a surface film and on work of deformation of the basis.

The reduction of the flow velocity due to the ejection of cryogenic liquid (excluding the influence of elastic concentrated masses) will occur to the level

$$
v=\frac{\pi d_{c}^{2} p_{b}}{2\left(\frac{\pi d_{c}^{2}}{4} \sqrt{2 p_{b} \rho}+Q_{k}\right)},
$$

$d_{c}$ - the diameter of the jet-forming (liquid) nozzle, $Q_{k}$-the consumption of cryogenic fluid, which should be taken into account in (2).

The ice generation occurs due to the transfer of heat $Q$ to the cryogenic flow by water particles, resulting in a phase transition and active cooling of the ice. Subsequently, the ice begins to actively absorb heat from the environment and gradually heat up:

$$
Q=Q_{n}+Q_{a}=c m T_{z}+L_{p} \rho h, \text { де } T_{z}=\frac{Q-L_{p} \rho h s}{c m} .
$$

Then, based on the Fourier positions on the equations of thermal conductivity and given that for heat runoff $Q=I d x d y d z d \tau$, where $I$ - the intensity of heat transfer from the medium to the ice; $d x d y d z$ - elementary volume of the ice, in the first approximation (at $d x d y d z=W_{k}$ and $\rho h s=m$ ) we have a temperature at the moment of collision with an obstacle:

$$
T_{z}=\frac{I W_{k} \tau-L_{p} m}{c m}
$$

$c$ - specific heat of the ice; $m$ - its averaged mass; $\rho$ - liquid density; $L_{p}$-specific heat of melting of ice; $h-$ crystallization layer over a period of time; $s$ - ice surface area. It enables finding $\sigma_{\mathrm{k}}{ }^{\mathrm{c}}$, that is, determining the cutting capabilities of the abrasive flow (according to [8]):

$$
\sigma_{\Omega}^{c \mathscr{H}}\left(T_{z}\right)=\left(-0,7375-0,859 T_{z}\right) 10^{6} .
$$

In accordance with the basic provisions of Acad. V.D. Kuznetsov, the energy of destruction $E_{p}$ is spent on increasing free surface energy $E_{n}$ on open separation surfaces and partially dissipates $\left(E_{\partial}\right)$ in the form of heat, wave processes, etc.: $E_{p}=E_{n}+E_{\partial}$. If we express the energy of destruction through the volume of destroyed material, then

$$
E_{p}=A \frac{W^{\prime} E_{n}}{a}
$$

where $a$-interatomic distance, $A$-coefficient of proportionality, $W^{\prime}$ - the amount of destroyed material per time unit. The latter is caused by the conditions of interaction of the flow and the surface film and is determined by the ability of ice particles to destroy the layer of contamination.

Then the process of removing contaminants from the surface of thin-walled shells with a hybrid tool of mechanical action will occur in several stages, according to Fig. 4.

Therefore, the use of a hybrid tool allows changing the kinetics of the cleaning process, and, based on the impulse action of bodies on elastic suspensions that perform self-oscillating motions in the flow, using the effect of impact cracking in a quasi-brittle surface film, extraction of which from the surface requires much less energy of the flow of ice particles. Such bodies make it possible to increase the destructive ability of the water-ice flow, because the strength of the ice particles is not sufficient to carry out intense damage to sulfide films of pollution. 


\section{Used equipment and tools}

For experimental studies we used laser-jet complex LSK-400-5, additionally equipped with the original icegenerating jet device, covered in detail in [9], Fig.5. The device enables the formation of water-ice flow with a variable opening angle $\alpha$ of the impact cone, as well as to change the twist of the supply flow (and, accordingly, the number Re) according to the need to generate ice of different fractional composition. The quality control of cleaning was carried out

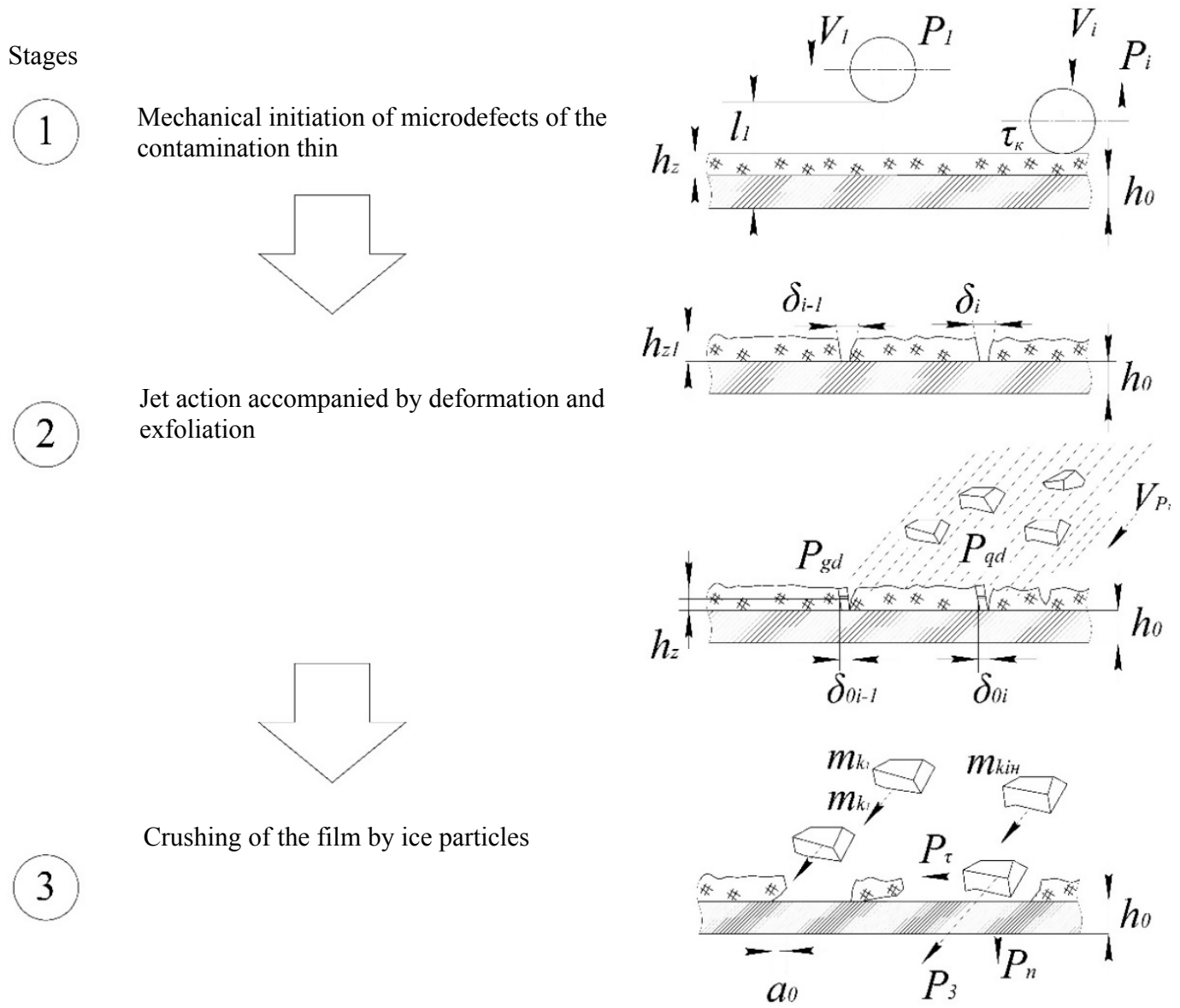

Fig. 4. Stages of cleaning the surface of the thin elastic shell from contamination

using the energy-dispersion method for determining the trace the micro-element composition of the surface layer [101], based on the method [11]. The researched surface of several zones was subjected to analysis, Fig. 6, (zones A-D), in each of which the composition of the products was determined by 8 points, with a step distance of $1.0 \mathrm{~mm}$. In this case it was assumed that the weight concentration of $C_{i}$ element $i$ is determined as

$$
C_{i}=(\mathrm{ZAF})_{i} J_{i} / J_{(i)} C_{(i)},
$$

where $C_{(i)}$ - weight fraction of the element in the standard; $Z_{i}$ - correction for the difference in the average atomic number between the sample and the standard, due to the reflection and inhibition of electrons; $A_{i}-$ correction for X-ray absorption in the sample is determined by the energy of the probe, the angle of exit of the X-ray radiation and the mass absorption coefficient for the investigated element of the sample; $F_{i}$ - correction for fluorescence due to secondary excitation of X-ray radiation of the element and radiation of other elements and brake radiation.

$\mathrm{Au}$ was used as a standard, for which there is a reference pur-file. The identified clusters of atoms of the substance corresponded to the contamination shown in Table 3.

Determination of the thickness of surface contamination was performed using a thickness gauge NOVOTEST TП-1. The resolution of the device with the sensor F- 0.3 is $\pm 3 \%$ of the measured value (the latter is in the range of $0 \ldots 300 \mu \mathrm{m}$ ). The experimental research was performed in the following sequence:

1. Before the tests, the test devices were installed and adjusted, the control and measuring equipment was placed in the test samples, auxiliary devices were prepared using a 3-D printer and the stand and measuring equipment were mounted; 


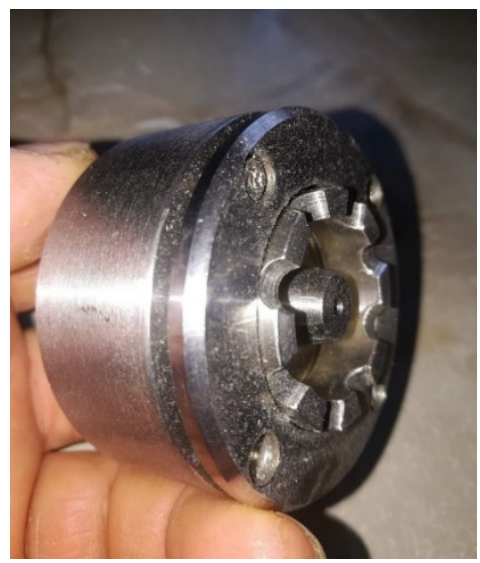

Fig. 5. A special water-ice device
Table 3. Detected atoms of substances and correspondence of contaminants

\begin{tabular}{|c|c|c|c|}
\hline No. & Substance atoms & Contaminant & Note \\
\hline 1 & $\mathrm{C}, \mathrm{O}, \mathrm{N}$ & lubricating contaminants & $\begin{array}{c}\text { Presence in more than } \\
5 \text { points }\end{array}$ \\
\hline 2 & $\mathrm{C}, \mathrm{O}, \mathrm{N}, \mathrm{S}$ & aromatic substances & $\begin{array}{c}\text { Presence in more than } \\
5 \text { points }\end{array}$ \\
\hline 3 & $\mathrm{O}$ & Oxides and hydroxides & $\begin{array}{c}\text { At some points on the } \\
\text { surface }\end{array}$ \\
\hline 4 & $\mathrm{Ca}, \mathrm{Na}, \mathrm{K}, \mathrm{Si}, \mathrm{O}$ & Insoluble salts & $\begin{array}{c}\text { At some points on the } \\
\text { surface }\end{array}$ \\
\hline 5 & $\mathrm{Si}, \mathrm{O}$ & Batch abrasive particles & Individual inclusions \\
\hline 6 & $\mathrm{~S}, \mathrm{O}$ & $\begin{array}{c}\text { Sulfides, sulfates of } \\
\text { oxidized surface layer }\end{array}$ & $\begin{array}{c}\text { At some points on the } \\
\text { surface }\end{array}$ \\
\hline
\end{tabular}

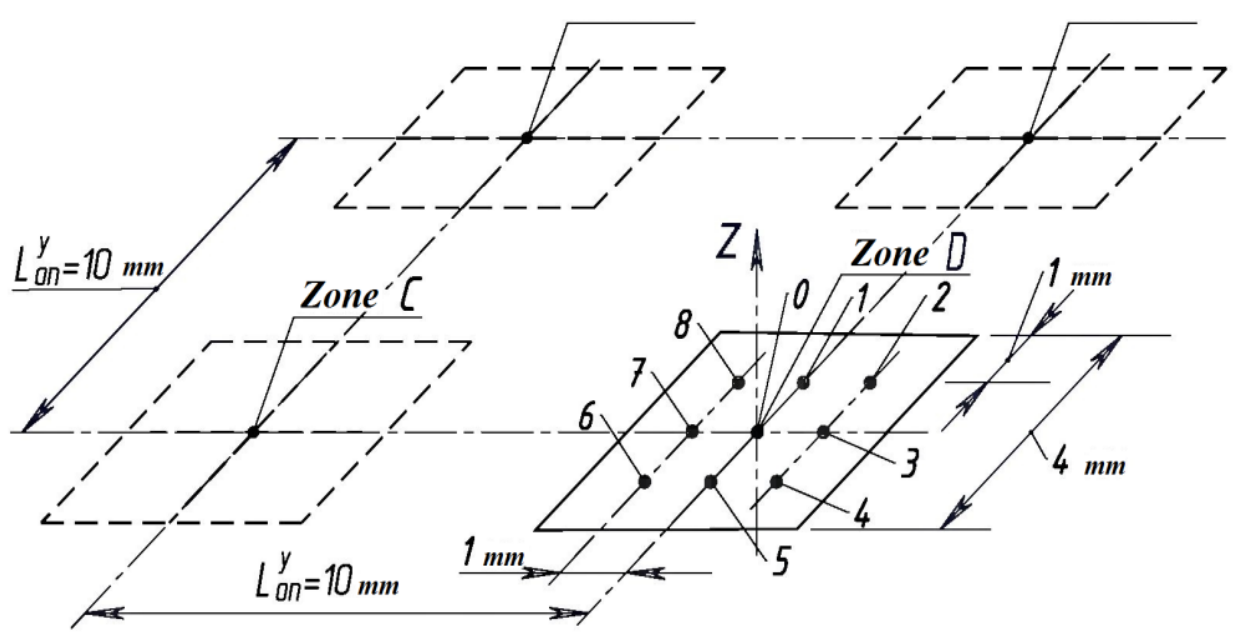

Fig. 6. Contamination control points on the test surface

2. The sensors were used to control the pressure of the liquid, its flow rate, the speed of movement of the jet head with cryogenic unit and pyrometers for setting temperatures $T_{1}$ and $T_{2}$ were pre-checked with data recording to a file via ADC m-DAQ and the accuracy of measurement data was determined;

3. According to the determined parameters of the jet system, the appropriate reports were filled in, the data were entered into the calculation tables, the measurements were performed 6 times, setting the average value and the confidence interval in accordance with the methods of statistical processing of experimental data;

4. According to the determined parameters of cryo-generation under known conditions of the jet action, the control temperatures of cryo-generation were determined, the data were written in files and the obtained sampling was processed. In this case the head was working no less than $5 \mathrm{~min}$ before the measurement, taking into account the change of the values of the controlled temperatures due to cooling of its flow part;

5. The parameters of heat flow $I$ were calculated, the size and mass and the fractionalism of the obtained ice particles were determined, as well as their strength $\sigma_{\mathrm{kr}}$. Reynolds number Re was calculated;

6. The cleaning efficiency was determined by the shape and area of cleaning per unit time, the microelectronic and energy dispersion research of the cleaned surface was performed.

\section{Research results}

Energy $E_{\Sigma}$, coming to the cutting zone from the flow of ice particles $E_{k}$, liquid component $E_{p}$ and mechanical impact $E_{m}$ as concentrated masses, suspended on elastic bonds, is spent on useful work of destruction $A_{p}$ a fairly small amount, and is approximately $5-7 \% E_{\Sigma}$. On the whole, it corresponds to results [11], and the difference is due to the conditions of formation of ice particles, their shape (and, accordingly, cutting properties), conditions of shock-cyclic 
loading of the surface by concentrated masses. However, the analysis of the ratio of energies (Fig. 7) spent on the motion of concentrated masses on elastic bonds and on the acceleration of ice particles (as well as the residual energy of the flow) proves, that excessive mass $m_{i}$ (excessive amount of mass), designated as $E m_{2}$ as well as insufficient one $\left(E m_{3}\right)$ lead to worse purification, expressed in terms of the relative degree of purification $F / F_{\max }$ (the relation of the completely cleaned surface area $F$ to a surface area that can be completely cleaned $F_{\max }$ with a stationary jet device during time $\tau$ ). In Fig. $7 E m_{1}$ corresponds to the case, when maximum surface cleaning can be achieved without the presence of residues of oxidation products and scale on the surface of the test shell. The presented results are typical of a thin layer of sulfide corrosion products $(0.07 \ldots 0.11 \mathrm{~mm})$, formed on the working blades of the turbine and in the cavities of the combustion chamber (thickness $0.55 \mathrm{~mm}$ ). However, experiments on other elements showed a slightly different result. Thus, it is established that an increase in the thickness of the base leads to a nonlinear decrease in index $F / F_{\max }$. This makes it possible to conclude about the importance of considering the process of cleaning surfaces in terms of elastic properties of the base, as well as the influence of Young's modules $E_{0}$ and $E_{z}$ on the description of the interaction of the film with concentrated masses $m_{i}$ on elastic bonds.

Therefore, the need for additional research aimed at identifying the functional conditionality of the modes of treatment of the parameters of the cleaning surfaces is obvious.

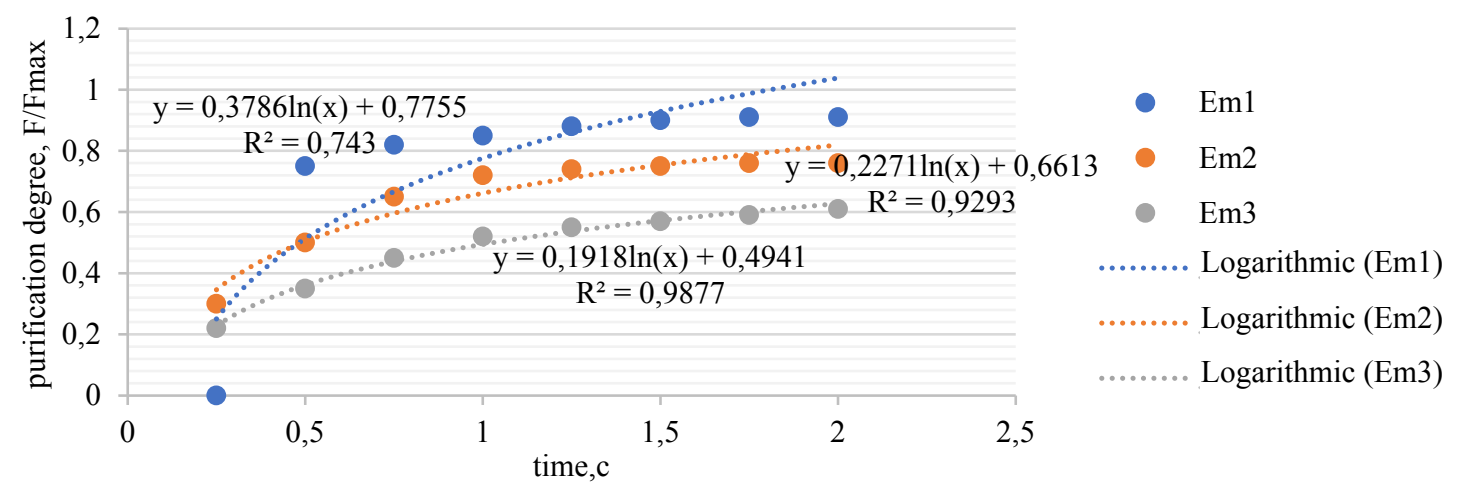

Fig. 7. The change of the degree of purification $F / F_{\max }$ at different relations of the energy spent on mechanical work (maintaining the oscillating motion of concentrated masses on elastic bonds) and on ice particles dispersion

In [12], we noted that the conditions of combination of liquid nitrogen with the fluid flow, as well as its consumption has a significant impact on the shape of the generated ice particles. This factor also affects the efficiency of cleaning operations. Thus, with the introduction of liquid nitrogen in an amount less than $10 \%$ of the flow rate of liquid (water), the ice particles are formed of acute geometric shape (Fig. 8), the size of the fractions is $0.09 \ldots 0.25 \mathrm{~mm}$, with an average weight of $0.007 \mathrm{~g}$. The increase in the consumption of liquid nitrogen leads to an almost linear increase in the mass of the ice, which generally coincides with the results of the calculation of the mass of the generated ice, but causes active inhibition of the flow, which reduces its energy. The displacement of the point of introduction of liquid nitrogen from the slice of the nozzle changes the fractional composition of the ice particles, their size, as well as the scattering of dimensions in a series of observations, table. 4.
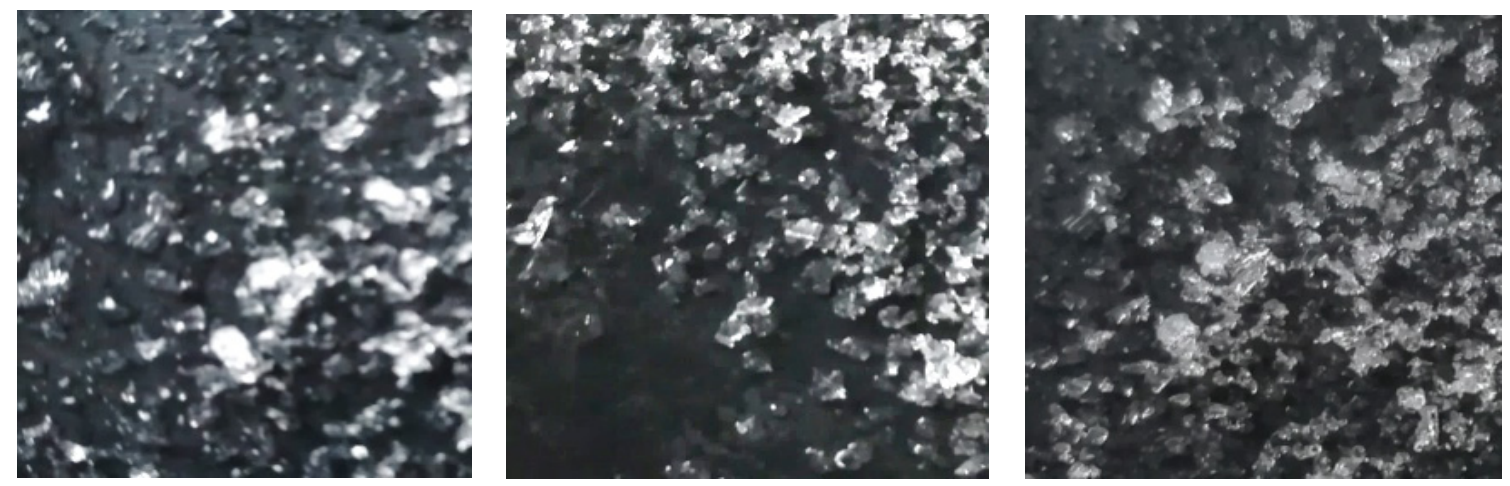

Fig. 8. Micrographs of ice particles obtained during the creation of fractograms; medium temperature $260 \mathrm{~K}$ 
Table 4. The results of research of the fractional composition of ice particles

\begin{tabular}{|c|c|c|c|c|}
\hline Generated ice particles & $\begin{array}{c}\text { Norm fraction, } \\
\mathrm{mm}\end{array}$ & $\begin{array}{c}\text { Medium size, } \\
\mathrm{mm}\end{array}$ & $\begin{array}{c}\text { Determined } \\
\text { dispersion, } \mathrm{mm}\end{array}$ & $\begin{array}{c}\text { Pirson } \chi^{2} \text { - criterion } \\
{\left[\chi^{2}\right]=3.84}\end{array}$ \\
\hline Small irregularly shaped & 0.1 & 0.085 & 0.022 & $2.95^{*}$ \\
\hline Small regularly shaped & 0.15 & 0.115 & 0.024 & $3.19^{*}$ \\
\hline Medium & 0.22 & 0.122 & 0.033 & $2.95^{*}$ \\
\hline Medium-large & 0.3 & 0.186 & 0.039 & $2.95^{*}$ \\
\hline Large & 0.4 & & & \\
\hline
\end{tabular}

${ }^{*} \chi^{2}<\left[\chi^{2}\right]$ that is, the hypothesis of the normality of the distribution is confirmed.

The question of reliability of cleaning of surfaces by the hybrid tool, and also changes of a cleaning stain over time remains important. Fig. 9 presents a diagram of the development of the cleaning spot over time for the scheme of action, which corresponds to Fig. 3, as well as a scan profile of the surface, which takes place at the point of action of the concentrated mass $m_{i}$.
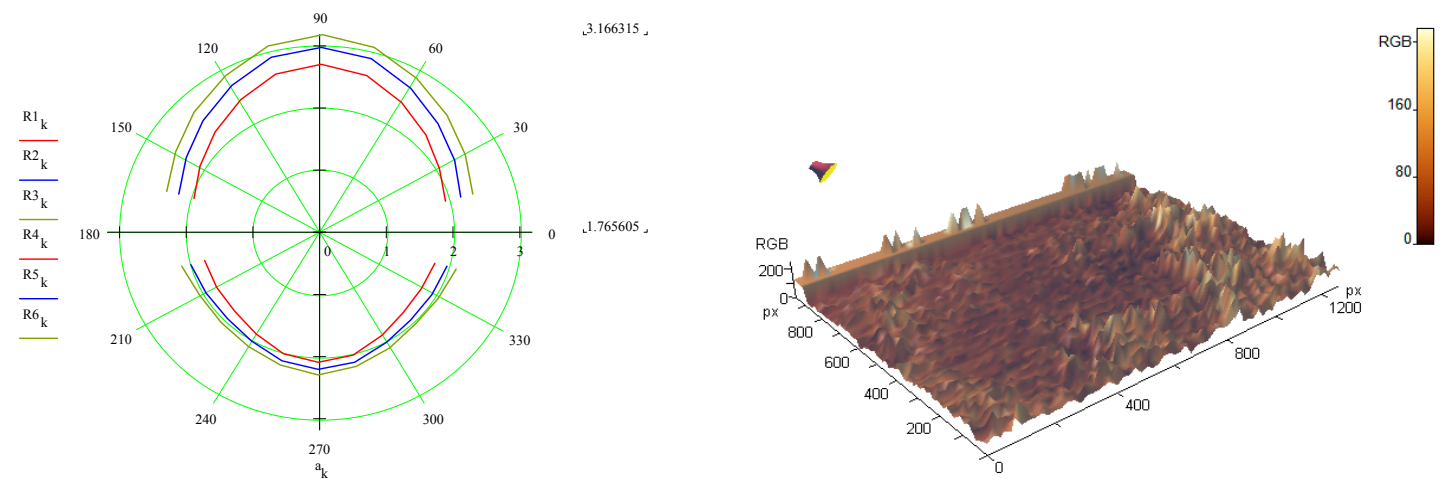

Fig. 9. The change of the size the cleaning stain over time $(a)$ and surface scan $(b)$ at the point of action of the concentrated mass on the cleaning surface. The surface is constructed according to the scheme of measurements of Fig. 6

Comparison of cleaning spots obtained by calculation and the photo of real surfaces proves that the cleaning area is predicted with an accuracy of up to $15 \%$ in the research of workpieces, the surfaces of which can be considered surfaces bounding the half-space and up to $20 \%$ with elastic surfaces in the form of shells.

It should be noted that in contrast to the known technical solutions, the cleaning efficiency (i, respectively, the area of the cleaned surface per time unit $\Delta \tau$ ) with the use of the proposed hybrid tool is more effective when the axis is located at angles greater than $\pi / 4$, Fig. 10 .

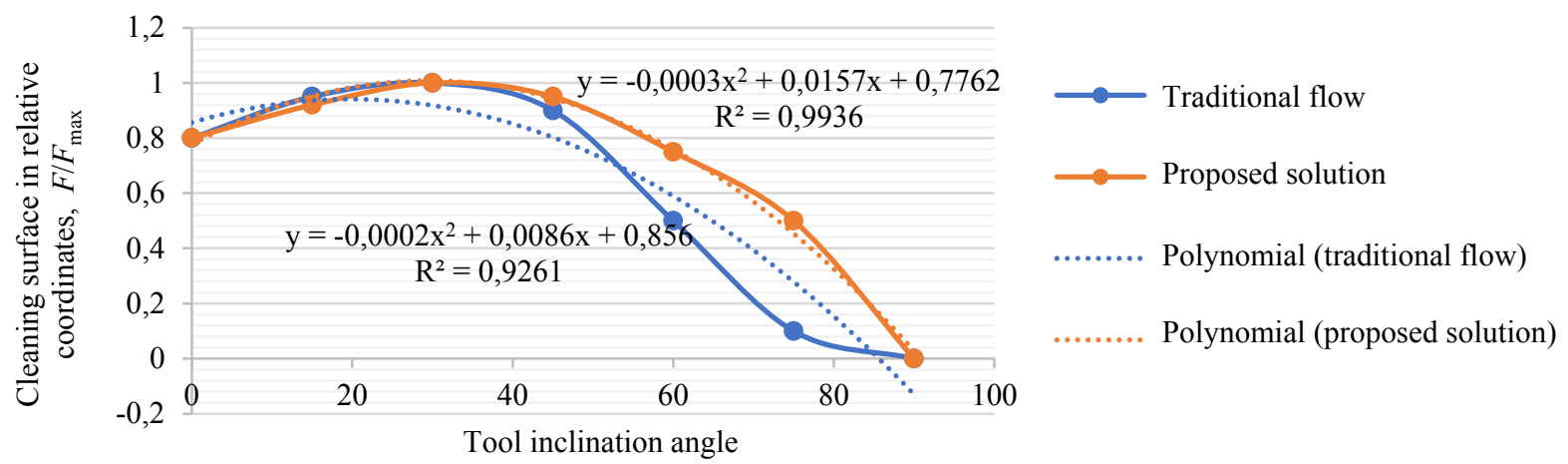

Fig. 10. Changing the cleaning area in relative coordinates $F / F_{\max }$ at different angles of location of the device axis for a typical and the proposed engineering solutions

При цьому максимальної ефективності очищення можна досягти при використанні пропонованих засобів, розташовуючи їх під кутами The maximum cleaning efficiency can be achieved by using the proposed tools, placing them at angles $\pi / 3-\pi / 6$. This is important for turbine units, as it is often difficult to orient the device so that the flow is perpendicular to the surface. 
Thus, using the proposed hybrid jet tool with additional small masses on elastic suspensions, capable of oscillating movements and shock-cyclic loading of the surface, it is possible to effectively perform cleaning of complex surfaces at angles in the range $\pi / 3-\pi / 6$. In this case the maximum fluid pressure does not exceed $90-110 \mathrm{MPa}$, and the consumption of cryogenic fluid for the formation of the flow of ice particles $-40-50 \mathrm{~g} / \mathrm{s}$.

\section{Conclusions}

The expediency of using a hybrid action tool for cleaning cavities and elements of turbine units, the operation of which is based on the combination of the action of water-ice flow with the mechanical impact of small concentrated masses mounted on elastic suspensions, is substantiated. Receiving energy from the flow, the masses, performing selfoscillating motion, come into contact with the treated surface having a layer of strong contamination, and create a multipoint shock-cyclic loading of the surface, which leads to active development of initial defects of the contamination film, due to which better and more productive cleaning is performed. It is shown that the generated local stresses, determined on the basis of Hertz contact problems, reach 15-20 MPa, do not have a significant effect on the surface of the base, which is a thin curved shell, do not change the state of its surface in the plane of adhesion, but result in defects in surface film in the form of cracks and delaminations. In this case, the extraction of the film by water-ice flow is more dynamic. Fractograms of the generated ice flow are obtained and their functional conditionality by generation modes and mixing chamber parameters is established.

The expediency of the use of tubeless mixing means is proved, which greatly simplifies the design, increases the reliability of the tool as a whole. The role of important factors on the quality of surface cleaning from contaminants inherent in turbine units is determined.

The use of water-ice jet, formed by the original tubeless device, makes it possible to form a wide (with a top angle $\pi / 12 \ldots \pi / 6$ ) flow, the work of its ice particles is spent on grinding the surface film.

Further research should be aimed at identifying the functional conditionality of the treatment modes by the parameters of the cleaning surfaces and design solutions of hybrid devices.

\section{References}

1. Orel V.N., Salenko A.F., Shchetynin V.T., Chencheva O.O. IMPROVING THE EFFICIENCY OF WATERJET PROCESSING DUE TO THE EFFECT OF INITIATED CRACKING Journal of the Technical University of Gabrovo. 2017. - Vol. 54, P. 7-13.

2. Ефективне гідрорізання: Монографія. - К.: ВІПОЛ, -2007. -488 с.

3. Wightman D.F. Waterjetting on the Cutting Edge of Machining / 7 SME MS86. Flexible Manufacturing Systems. Chicago, 1986. - Vol. 2. $-171 \mathrm{p}$.

4. Степанов Ю.С., Качанов А.Н., Бурнашов М.А. Определение величины деформации материала в зоне резания при раскрое водоледяным инструментом. ПОЛЗУНОВСКИЙ ВЕСТНИК. - 2009. - № 1-2. - С. 272-279.

5. Орел В.Н., Щетинин В.Т., Саленко А.Ф., Яцина Н.Н. The use of controlled cracking to improve the efficiency of waterjet cutting, Eastern-European Journal of Enterprise Technologies. - 2016. - Vol. 1, No. 7. - C. 45-56. https://doi.org/10.15587/1729-4061.2016.59907

6. Гідро- та гідроабразивна обробка: теорія, технологія та обладнання. К.: в-во ВІПОЛ, $-2001 .-488$ с.

7. Бурнашов М.А., Головин К.А. Экспериментальные исследования применения водоледяного инструмента для раскроя рулонных и листовых материалов // Социально-экономические и экологические проблемы горной промышленности, строительства и энергетики: матер. Межд. конф. / ТулГУ. Тула. - 2008. - С. 117-121.

8. Планковский С.И., Головин И.И., Сиренко Ф.Ф. Анализ существующих методов очистки поверхности лопаток турбин в газотурбинных двигателях-Авиационно-космическая техника и технология, - 2013. - Т. 103, № 6. С. $27-34$.

9. Медведев А.А., Посеренин А.И. Применение энергодисперсионных рентгеновских спектрометров для элементного анализа геологических образцов. - Горный информационно-аналитический бюллетень. - 2016. - № 11. С. 115-124.

10. Толоконников И.А. Энергодисперсионный рентгенофлюоресцентный анализатор состава вещества РеСПЕКТ // Атомная энергия. - 2003. - Т. 95. - Вып. 1. - С. 69-70.

11. Саленко О.Ф. Інструмент інтегральної дії для виконання струминно-абразивного очищення / О.Ф. Саленко, П.Б. Поздняков // Надійність інструменту та оптимізація технологічних систем: зб.наук.праць. - Краматорськ, 2007. - Вип. 22. - С. 93-98.

12. Use of water-jet means for cleaning operations of turbine units // Journal of the Technical University of Gabrovo, - No. 59, P. 32-55.

\section{Інструмент гібридної дії для операцій очищення порожнин турбоагрегатів}

\section{Ткачук Віталій, Щетинін Віктор, Шлик Сергій, Ченчева Ольга, Саленко Олександр}

Анотація. Розглядається інструмент гібридної дії для очищення порожнин і елементів турбоагрегатів, робота якого грунтується на сполученні дії водо-крижаного потоку із механічним ударним впливом малих зосереджених мас, змонтованих на пружних підвісах. Отримуючи енергію від потоку, маси, здійснюючи автоколивальний рух, контактують 
із оброблюваною поверхнею, щңо має шар міцного забруднення, і створюють багатоточкове ударно-циклічне навантаження поверхні, яке веде до активного розвитку початкових дефектів плівки забруднення, внаслідок чого наступна дія водокрижаного потоку викликає більш якісне та продуктивне очищення. Показано, що створювані локальні напруження, визначені на основі контактних задач Гериа, сягають 15-20 МПа, не мають істотного впливу на поверхню основи, якою $\epsilon$ тонка криволінійна оболонка, не змінюють стан ї̈ поверхні в площині адгезійного зчеплення, однак ведуть до виникнення дефектів у поверхневій плівиі у вигляді тріщин та відщарувань. У иъьому випадку вилучення плівки водо-крижаним потоком відбувається більш динамічно. Застосування водо-крижсаного струменя, сформованого оригінальним безкамерним пристроєм, дозволяе формувати широкий (з кутом при верхівиі $\pi / 12-\pi / 6)$ потік, робота крижинок якого витрачається на подрібнення поверхневої плівки. Розтічний струмінь очищує поверхню та виносить продукти руйнування за меж впливу.

Використання гібридного інструменту дозволило підвищити продуктивність обробки з кутами натікання струменя, відмінними від $\pi / 2$, у понад $30 \%$, при иьому витрата кріогенної рідини (рідкого азоту) зменщена на 20-25\%.

Виконане моделювання процесу, оцінено умови порушення адгезивного зв'язку плівки бруду із поверхнею, визначено умови його раціонального виконання.

Ключові слова: гібридний інструмент, водо-крижаний потік, очищення поверхні, моделювання, поверхневі плівки.

\section{Инструмент гибридного действия для операций очистки полостей турбоагрегатов}

\section{Ткачук Виталий, Щетинин Виктор, Шлик Сергей, Ченчева Ольга, Саленко Александр}

Аннотация. В статье рассматривается инструмент гибридного действия для очистки полостей и элементов турбоагрегатов, работа которого основана на сочетании воздействия водо-ледяного потока с воздействием механического удара небольших концентрированных масс (ударников), установленных на упругих подвесах. Получая энергию от потока, ударники, совершая автоколебательные движения, вступают в контакт с обрабатываемой поверхностью, имеющей слой загрязнения, и создают многоточечное ударно-циклическое нагружение, что приводит к активному развитию начальных дефектов в слое загрязнения, благодаря чему последующее действие водо-ледяного потока обеспечивает лучшую и более производительную очистку. Показано, что генерируемые локальные напряжения, определяемые на основе контактных задач Гериа, достигают 15-20 МПа, и не оказывают существенного влияния на очищаемую поверхность в виде тонкой криволинейной оболочки, вызывая только развитие дефектов в пленке в виде трещин и отслоений. $B$ этом случае пленка удаляется потоком водяного льда более динамично. Использование водо-ледяного потока, образованного оригинальнылм бескамерным устройством, позволяет формировать достаточно широкий поток (с углом $\pi / 12 \ldots \pi / 6)$, а работа его частии льда расходуется на измельчение пленки загрязнения; при этом струйный поток очищает поверхность и удаляет продукты разрушения за предель зоны воздействия.

Использование гибридного инструмента позволило повысить производительность обработки при углах смачивания струйного потока, отличаютихся от $\pi / 2$, более чем на $30 \%$, а расход криогенной жидкости (жидкого азота) снижается на $20-25 \%$

Выполнено моделирование прочесса, оченены условия разрушения адгезионной связи пленки загрязнения с поверхностью, определены условия рациональных режимов прочесса.

Ключевые слова: гибридный инструмент, водо-ледяная очистка поверхности, моделирование, поверхностные грязевые пленки.

References

1. Orel, V.N., Salenko, A.F., Shchetynin, V.T. and Chencheva, O.O. (2017), "Improving the efficiency of waterjet processing due to the effect of initiated cracking", Journal of the Technical University of Gabrovo, no. 54, pp. 7-13.

2. Effective hydrocutting (2007), Monograph, VIPOL

3. Wightman, D.F. (1986), Waterjetting on the Cutting Edge of Machining, 7 SME MS86, Flexible Manufacturing Systems, Chicago, USA.

4. Stepanov, Yu.S., Kachanov, A.N. and Burnashov, M.A. (2009), Determination of the size of deformation of material in the cutting zone during cutout by water0ice tool, POLZUNOVSKII Bulletin, No. 1-2, pp. 272-279.

5. Orel, V.N., Shchetynin, V.T., Salenko, A.F. and Yatsyna, N.N. (2016), "The use of controlled cracking to improve the efficiency of waterjet cutting”, Eastern-European Journal of Enterprise Technologies, vol. 1, no. 7, pp.45-56. https://doi.org/10.15587/1729-4061.2016.59907

6. Hydro- and hydro-abrasive treatment: theory, technology and equipment (2001), VIPOL.

7. Burnashov, M.A. and Golovin, K.A. (2008), Experimental research of the application of water-ice tool for the cutout of roll and sheet materials, Social-economic and ecological problems of mining industry, construction and power engineering: mater. Of Intern. Conf., TulSU, Tula, pp. 117-121.

8. Plankovskii, S.I. Golovin, I.I. and Sirenko, F.F. (2013), "The analysis of the existing methods for purification of the turbine blades in gas turbine engines", Aviation-space technology, vol. 103, no. 6, pp. 27-34.

9. Medvedev, A.A. and Poserenin, A.I. (2016), Application of energy dispersion X-ray spectrometers for the element analysis of geological samples, Mining information analytical bulletin, no. 11, pp. 115-124.

10. Tolokonnikov, I.A. (2003), "Energy dispersion X-ray-fluorescent analyzer of substance composition ReSPEKT", Atomic energy, vol. 95, no. 1, pp. 69-70.

11. Salenko, O.F., Salenko, O.F. and Pozdniakov, P.B. (2007), "Integral action tool for jet-abrasive purification", Reliability of tools and optimization of technological systems: Collection of papers, Kramatorsk, no. 22, pp. 93-98.

12. "Use of water-jet means for cleaning operations of turbine units", Journal of the Technical University of Gabrovo, no. 59, pp. 32-55. 